\title{
A ESTRATÉGIA JUDICIAL DOS MOVIMENTOS SOCIAIS DE LUTA POR MORADIA URBANA NO ÂMBITO DAS AÇÕES POSSESÓRIAS
}

\author{
THE LEGAL STRATEGY OF SOCIAL MOVEMENTS IN THE \\ STRUGGLE FOR URBAN HOUSING IN THE LITIGATION OF \\ POSSESSORY LAWSUITS
}

\author{
Josué Mastrodi ${ }^{1}$ \\ Verônica Elisa Soares Barbosa ${ }^{2}$
}

\section{RESUMO}

Este artigo é resultado de pesquisa realizada sobre processos judiciais envolvendo a posse ou a propriedade de imóveis ociosos ocupados por movimentos de luta por moradia urbana. Procurou-se entender a estratégia de defesa dos movimentos sociais visando à manutenção dos ocupantes na posse do imóvel ocupado e objeto da disputa judicial. A pesquisa teve por objeto saber quais seriam os argumentos de defesa e se os movimentos sociais se utilizam de normas de direitos humanos para fundamentar sua posição. Em especial, se os movimentos sociais buscariam proteção judicial diferenciada em favor das crianças ocupantes, de modo a lhes garantir direitos fundamentais ao desenvolvimento infantil saudável. Esta pesquisa consistiu na análise processual de ações possessórias configuradas como conflitos fundiários urbanos conforme Resolução n. 87/2009 do Conselho Nacional das Cidades (ConCidades), em que os envolvidos são ocupações por moradia na cidade de Campinas, no período entre 2014 e 2018. A análise processual pôs foco principalmente nos argumentos de defesa (contestação, petições intermediárias, apelação, embargos de declaração e agravos de instrumentos contra liminares de reintegração de posse).

\section{PALAVRAS-CHAVE:}

Direito à cidade. Direitos da criança. Movimentos sociais de moradia. Ações possessórias. Estratégias de defesa.

\begin{abstract}
This article is the result of a research done on civil lawsuits involving the possession of idle private real estate by social movements for urban housing. It was sought to understand the strategy behind the social movements' defense seeking the maintenance of the occupants' possession over the property they are inhabiting, as well as the object of the judiciary dispute. The objective was to understand which are the arguments that could be presented by the defense

\footnotetext{
${ }^{1}$ Doutor em Teoria Geral e Filosofia do Direito pela Universidade de São Paulo e Professor dos Programas de Pós-Graduação Stricto Sensu em Sustentabilidade e em Direito da Pontifícia Universidade Católica de Campinas. ${ }^{2}$ Mestranda em Direitos Humanos e Desenvolvimento Social na Pontifícia Universidade Católica de Campinas (PUC-Campinas). Integra o Grupo de Estudos "Direito e Realidade Social", sob orientação do Professor Dr. Josué Mastrodi Neto.
} 
and if the social movements make use of the Human Rights system to support their statement. Specifically, if the social movements would ask for differentiated judicial protection in favor of the occupant children, in order to assure them their fundamental right to a healthy childhood. This research consisted of a processual analysis on possessory lawsuits classified as urban land disputes in conformity with the Resolution n. 87/2009 of the Nacional Council of Cities (ConCidades), where the parties are social movements for housing in the city of Campinas, during the period between 2014 and 2018. The analysis focused primarily on the argumentative thesis of defense (responses, intermediate petitions, appeals, motions for clarification, bills of review proposed against preliminary decisions in favor of repossession).

\section{KEYWORDS:}

Right to the city. Children's rights. Social movements for urban housing. Possessory lawsuits. Defense strategies.

\section{INTRODUÇÃO}

O artigo aborda a estratégia defesa dos movimentos sociais de luta por moradia urbana em processos judiciais possessórios, e verifica se a proteção normativa especial conferida a crianças ocupantes tem sido utilizada como parte desta estratégia. Como as crianças gozam de proteção estatal diferenciada pelo ordenamento jurídico, procurou-se saber se os movimentos sociais utilizariam tal arcabouço normativo para promover a proteção da ocupação ou, no limite, em caso de desocupação, condicioná-la a identificação prévia de destino para as crianças filhas dos ocupantes.

Os movimentos sociais de luta por moradia urbana promovem a ocupação de áreas que não cumprem a função social da propriedade (artigo $5^{\circ}$, XXIII da Constituição Federal) como forma de pressionar o Estado para prover soluções para o déficit habitacional. Tais áreas urbanas ocupadas, apesar de não exercerem a função social da propriedade, ${ }^{3}$ são áreas cujos proprietários tendem a buscar a tutela judicial de seu direito de propriedade por meio de ações possessórias ou reivindicatórias, como estipulado pelo artigo 1.228 do Código Civil.

\footnotetext{
${ }^{3}$ O Plano Diretor do Município de Campinas, SP (cujo território é analisado na pesquisa), baixado pela Lei Complementar n. 189/2018, define a função social da propriedade em seu artigo $2^{\circ}$, inciso II, como o uso da propriedade urbana e rural, visando ao bem-estar coletivo, à redução da terra ociosa e à distribuição equilibrada de usos no território, cumprindo as exigências fundamentais de planejamento, ordenamento e gestão da política do território.
} 
O Estado, que não contempla a promoção de políticas de habitação para quem não tem condições de financiar imóveis (isto é, que não tem como entrar na lógica de mercado e realizar o sonho da casa própria), é pródigo em promover, por meio do Poder Judiciário, a desocupação de imóveis, ainda que comprovadamente ociosos, e sem prover soluções alternativas à desocupação. Exemplos não faltam, como o ocorrido no ano de 2012 na Ocupação Pinheirinho em São José dos Campos, SP, onde a população ocupante sofreu com duras investidas do Estado em ação de reintegração de posse, acarretando inúmeras violações de Direitos Humanos. Nesse contexto, ocupar o imóvel sem função social e manter a ocupação é a única possiblidade de moradia para seus ocupantes.

Em que pese o conteúdo constitucional do direito fundamental à moradia e da determinação, também constitucional, de que a propriedade deve cumprir sua função social, a legislação ordinária permite ao juiz que determine a desocupação imediata de áreas ocupadas há menos de ano e dia (por meio da expedição do mandado liminar de manutenção ou reintegração de posse), ou que determine a desocupação ao final do processo em caso de ocupações havidas há mais tempo.

As coordenações dos movimentos sociais registram as crianças junto a creches, escolas e postos de saúde, a fim de assegurar os direitos sociais e fundamentais, forçando a aplicação da proteção normativa em torno do sujeito criança ${ }^{4}$, e pressionando o Estado a proteger as crianças para que não ocorra nenhuma violação de seus direitos ${ }^{5}$.

Esta situação acaba, assim, sendo relevante, principalmente durante o período de ocupação ou em caso de desocupação involuntária, já que, conforme itens 4 e 10 do Comentário Geral n. 7 do Comitê para Direitos Econômicos, Sociais e Culturais da Organização das Nações Unidas (ONU), a prática de desocupações (forçadas) pode ocasionar em violações a vários direitos civis e políticos, como os direitos à vida, à segurança pessoal e à dignidade humana. Reconhecendo que as crianças, para seu pleno e harmonioso desenvolvimento físico e

\footnotetext{
${ }^{4}$ A proteção normativa em torno da criança se dá, no âmbito nacional, principalmente, pelo Estatuto da Criança e do Adolescente (Lei n. 8.069/ 1990) e, no internacional, pela Declaração Universal dos Direitos da Criança e a Convenção Internacional sobre os Direitos da Criança (Decreto n. 99.710/1990, base para a redação do Estatuto da Criança e do Adolescente).

5 No item 4 do Comentário Geral n. 7 do Comitê das Nações Unidas para Direitos Econômicos, Sociais e Culturais está disposto que a prática de desocupações forçadas pode ocasionar violações a vários direitos civis e políticos, como os direitos à vida, à segurança pessoal e à dignidade humana.
} 
psicológico na sociedade, ${ }^{6}$ devem receber, como grupo vulnerável, mais proteção e assistência especial, especialmente em situações como a de uma desocupação forçada.

A prévia identificação de destinos seguros para estas crianças, devidamente definidos pela Administração Pública, ${ }^{7}$ é uma das práticas que asseguraria seus direitos fundamentais, como sujeitos vulneráveis, que podem ter sua situação de vulnerabilidade agravada pela realização de desocupações involuntárias. ${ }^{8}$

Assim, a proteção estatal diferenciada conferida pelo ordenamento jurídico à criança, é uma das estratégias, fundamentada na utilização do arcabouço dos Direitos Humanos, a ser utilizada pelos movimentos sociais, para a manutenção da ocupação ante decisão judicial de desocupação e, também, para evitar as decisões de desocupação que tenham como ponto central a execução por meio de força policial, sem a prévia identificação dos sujeitos de direito à proteção assistencial, e nesta situação, as crianças ocupantes devem ter garantia ao desenvolvimento saudável infantil, em conformidade com seus direitos sociais e fundamentais, principalmente, ao acesso educação, saúde e convívio familiar (artigo 227 da Constituição Federal).

60 reconhecimento da criança como sujeito vulnerável é disposto pela primeira vez na Declaração Universal dos Direitos Humanos da ONU em 1948. Sendo reiterado, principalmente, com mais especificidade na Declaração sobre os Direitos da Criança e na Convenção Internacional sobre os Direitos da Criança. Ressalte-se que todos esses diplomas internacionais foram ratificados pelo Estado brasileiro.

7 A Resolução n. 10, de 17 de outubro de 2018, publicado pelo Conselho Nacional dos Direitos Humanos (órgão vinculado atualmente ao Ministério da Mulher, da Família e dos Direitos Humanos) dispõe no artigo 15, a necessidade de realizar nas remoções inevitáveis, plano de prévio de remoção e reassentamento e, no artigo 14, que os deslocamentos não deverão resultar em pessoas sem teto, como também que tais práticas não deveriam ser realizadas quando afetarem o acesso à educação e assistência de crianças e adolescentes. Além desta Resolução, o Ministério Público Estadual de São Paulo, pela Procuradoria Geral de Justiça, expediu o aviso n. 42/12 para que, em processos que envolvam crianças e idosos, o Poder Público promova assistência mediante cadastramento e alocação das famílias em alojamentos e abrigos adequados, a serem definidos das reuniões preparatórias das operações de cumprimento de reintegração de posse.

8 O Comentário Geral n. 7 do Comitê das Nações Unidas para Direitos Econômicos, Sociais e Culturais, em seu item 10 dispõe: "Women, children, youth, older persons, indigenous people, ethnic and other minorities, and other vulnerable individuals and groups all suffer disproportionately from the practice of forced eviction. Women in all groups are especially vulnerable given the extent of statutory and other forms of discrimination which often apply in relation to property rights (including home ownership) or rights of access to property or accommodation, and their particular vulnerability to acts of violence and sexual abuse when they are rendered homeless. The nondiscrimination provisions of articles 2.2 and 3 of the Covenant impose an additional obligation upon Governments to ensure that, where evictions do occur, appropriate measures are taken to ensure that no form of discrimination is involved". 
Esta pesquisa, para além da abordagem bibliográfica, é empreendida no estudo das ações judiciais da classe possessória ${ }^{9}$ com características de conflito fundiário urbano, ${ }^{10}$ envolvendo ocupações por moradia, protocolizadas no período de 2014 a $2018^{11}$ na cidade de Campinas, SP. A coleta de material envolveu inicialmente a pesquisa dos processos via portal eletrônico de serviços $e$-SAJ do Tribunal de Justiça de São Paulo, ${ }^{12}$ por meio das consultas de processos do $1^{\circ} \mathrm{grau}$.

A partir desse mecanismo, os filtros usados nos dois foros da Comarca de Campinas (Foro da Cidade Judiciária e Foro Regional de Vila Mimosa) ${ }^{13}$ foram definidos com os seguintes critérios. No espaço sob designação nome da parte, foram inseridos os termos MST; moradia; invasores; e ocupantes encontrando-se ao todo 137 processos. No foro da Cidade Judiciária, foram achados 91 processos, sendo encontrado o único processo (no critério territorial adotado) em que umas das partes é qualificada por MST (Movimento dos Trabalhadores Rurais sem Terra). No que se refere ao Foro Regional de Vila Mimosa, a pesquisa resultou nos 46 processos restantes (daqueles 137).

É importante destacar que os 137 processos encontrados por essa busca inicial não terão suas análises trazidas neste artigo, já que, além do critério territorial adotado, estabelecemos o critério temporal (do ano de 2014 a 2018), limitando o número em 66 processos, como também o critério de classe processual (ações possessórias) e critério subjetivo (uma das partes processuais deve ser ocupação por moradia urbana) ${ }^{14}$. Ao final desta filtragem, foram

\footnotetext{
${ }^{9}$ As ações possessórias, de acordo com o Código de Processo Civil de 2015, são as ações de reintegração de posse, interdito proibitório e manutenção da posse.

${ }^{10}$ Adotamos a compreensão de Conflito fundiário urbano disposto na Resolução n. 87/2009 do Conselho Nacional das Cidades (ConCidades), órgão colegiado deliberativo e consultivo, criado em 2004 como instrumento do Ministério da Cidades, extinto em 2019. Atualmente, o ConCidades é órgão ligado ao Ministério do Desenvolvimento Regional, conforme informado no portal de internet do Governo do Brasil.

${ }^{11}$ Estabelecido o critério territorial (Comarca de Campinas), foi necessário entender de que forma a análise processual seria mais propícia no seu objetivo. Definimos o ano de 2014 como ponto de partida, já que foi quando os processos da Comarca de Campinas iniciaram seu andamento totalmente digital. Todos os processos originados de ações possessórias configuradas como conflitos fundiários urbanos até o ano de 2018 foram objeto desta pesquisa.

12 Disponível em: https://esaj.tjsp.jus.br/esaj/portal.do?servico=190090.

${ }^{13}$ Como a pesquisa se restringiu à cidade de Campinas, o foro regional de Paulínia -que pertence à comarca de Campinas, mas cuja competência territorial se dá apenas sobre o município de Paulínia- não foi pesquisado.

${ }^{14}$ Para identificar os processos de classe possessória envolvendo ocupações por moradia urbana foi necessário analisar os 66 processos e encontrar os elementos em comum dos polos passivos com referência as características dos movimentos sociais de luta por moradia urbana, bem como as de conflito fundiário urbano.
} 
encontrados 8 processos da Comarca de Campinas, do período de 2014 a 2018, originados por ações da classe possessória.

A fim de se certificar dos números de processos dentro do corte adotado pela pesquisa, ainda por meio do portal eletrônico do TJ-SP em consultas de jurisprudência, averiguamos as ações contidas nesse banco de pesquisa e, por meio do filtro com as palavras-chaves, moradia E ocupação, moradia E MST, moradia E invasores, no assunto esbulho/turbação/ameaça e interdito possessório na Comarca de Campinas, por origem de $2^{o}$ grau e Colégios recursais e publicações de tipo de acórdãos, homologações de acordo e decisões monocráticas, encontramos 20 ações (11 ações pertencente ao lapso temporal), sendo apenas 1 processo dentro dos critérios estabelecidos, sob o número 1053501-39.2016.8.26.0114, mas que está em segredo de justiça pelos termos da Resolução normativa n. 121 do CNJ. ${ }^{15}$

Dessa forma, totalizaram 8 ações possessórias, dentro dos critérios estabelecidos para essa análise, sendo elas ${ }^{16}$ as da Ocupação Nelson Mandela I e II, da Ocupação Vivenda-Itayu, da Ocupação Vila Paula I e II, da Ocupação do Prédio Padova, ${ }^{17}$ da Ocupação Itatinga e da Ocupação Movimento Comunidade da Família por Moradia, que tramita em segredo de justiça. Os movimentos sociais de luta por moradia apresentaram defesa judicial em todos os

\footnotetext{
15 A Resolução normativa n. 121, de 05 de outubro de 2010, dispõe sobre a divulgação de dados processuais eletrônicos na rede mundial de computadores, expedição de certidões judiciais e das outras providências. No que tange a divulgação dos atos processuais, o exercício da publicidade restrita ou especial dos atos é garantido pelo artigo 93, XI, da Constituição Federal, segundo a qual a divulgação pode e deve ser restringida sempre que a defesa da intimidade ou o interesse público o exigir.

${ }^{16}$ A Ocupação Nelson Mandela se auto identifica como um movimento uno. Contudo, para apresentação clara das diferenças do movimento nos processos encontrados, foi convencionada a distinção (Nelson Mandela I e II), já que existem dois processos de reintegração de posse em face da Ocupação Nelson Mandela. Essa convenção também ocorreu na apresentação da identificação da Ocupação Vila Paula que, neste trabalho, também será mencionada conforme os processos em face da ocupação, pois tramitam duas ações possessórias em varas de competências distintas, quais sejam, $7^{\text {a }}$ Vara Cível da Comarca de Campinas (Vila Paula I) e $1^{\text {a }}$ Vara da Fazenda Pública (Vila Paula II) Além disso, as Ocupações nomeadas nesse artigo como Ocupação Itatinga e Ocupação do Prédio Padova foram identificadas assim em referência à propriedade ocupada, pois os autores não qualificaram as ocupações. Nesse aspecto, as Ocupações Nelson Mandela I e II, Vila Paula I e II, Movimento Comunidade da Família por Moradia e Vivenda-Itayu, são identificadas desta forma, em conformidade com as manifestações das próprias ocupações nos autos de seus respectivos processos ou recursos.

17 Às vésperas da submissão deste artigo, houve andamento processual em que oficial de justiça, por força do mandado n. 114.2019/123499-0, realizou diligências no endereço da Ocupação, constando conforme certidão de mandado cumprido positivo (fls. 219-220), que "os moradores atuais reuniram-se em formato de associação de nome Associação Grito por Moradia, representando os demais moradores e promovendo a organização e as melhorias nas condições do edifício”.
} 
respectivos processos de reintegração de posse, menos no caso das Ocupações Itatinga e Prédio Padova. $^{18}$

Esta pesquisa analisou, em especial, se nas argumentações propostas em defesa das Ocupações (contestação, petições intermediárias, apelação, embargos de declaração e agravos de instrumentos contra liminares de reintegração de posse) foi disposta tese de proteção diferenciada à criança e, se assim, teria sido garantida a manutenção das Ocupações ou se eventual desocupação teria ocorrido levando tal proteção em conta.

\section{CONSIDERAÇõES METOdOLÓGICAS: AUSÊNCIA, NOS PROCESSOS, DE INDIVIDUALIZAÇÃO DOS MOVIMENTOS SOCIAIS DE LUTA POR MORADIA URBANA}

A invisibilidade das desocupações foi o principal desafio desta análise. Para equacionar e construir uma pesquisa confiável, que permitisse o embasamento teórico pautado na realidade social vivenciada pelas ocupações (e pelas crianças ocupantes), foi necessário recorrer a várias fontes, o que gerou outros desafios, como a análise de dados incompletos ou fragmentados, como também a ausência de estatísticas públicas do município analisado.

Nesta análise, algo que nos causou estranheza foi fato de o Poder Judiciário aceitar o recebimento e dar andamento às ações possessórias mesmo com a qualificação incompleta do movimento social a constar do polo passivo, ${ }^{19}$ gerando limitação na pesquisa, pois a imprecisão

\footnotetext{
${ }^{18}$ Ao analisar os autos da Ação Possessória da Ocupação Itatinga, verificamos que não houve propriamente a defesa pela Ocupação, pois ocorreu, no momento da citação, falsa identificação dos ocupantes, como se fossem oriundos de algum movimento social, assim o polo passivo citado não era integrante da ocupação, mas ocupava um lote paralelo à propriedade ocupada e tinha sua posse há mais de 10 anos, pleiteando usucapião em ação distinta e alegando sua posse nos autos da ação que envolve sua ocupação. Já no caso da Ocupação Prédio Padova, existe identificação do polo passivo pela petição inicial, que qualifica duas pessoas como ocupantes e participantes do movimento, mas pela análise processual não há condições de conferir a qualificação, já que não ocorreu a citação, muito menos defesa judicial pelo movimento social que promove essa Ocupação.

${ }^{19}$ O Código de Processo Civil de 2015 dispõe sobre hipóteses de aceite e prosseguimento da petição inicial (artigo 319), mesmo que, não seja instruída com as informações requeridas pelo texto normativo para individualização concreta do polo passivo, quais sejam as hipóteses: (i) se o polo ativo não dispuser de tais informações, deve requerer diligências necessárias à sua obtenção; (ii) se for possível a citação mesmo sem as informações corretas sobre o réu; e (iii) se a obtenção de tais informações for impossível ou excessivamente onerosa à justiça. Ademais, acerca das ações possessórias, o Código de Processo Civil adota especificidade na citação, que deve ser pessoal e
} 
em denominar o polo passivo impede sabermos se o réu da possessória é ou não um movimento social. Os proprietários dos imóveis ocupados, autores das ações possessórias, dificilmente qualificam o movimento social ou os ocupantes de modo preciso.

A qualificação incompleta ou parcial ${ }^{20}$ consiste em não indicar o nome do movimento social ou dos ocupantes, apresentando os réus no processo como desconhecidos ou invasores; em alguns casos, foi dado o nome de um movimento social qualquer, sem relação com a ocupação do imóvel, ou identificaram como ré uma única pessoa físicaocupante. ${ }^{21}$

A falta da qualificação correta dos polos passivos das ações possessórias foi fator limitante desta pesquisa, fato que não causou problemas apenas para a pesquisa, mas também para a defesa das ocupações, em ao menos mais três circunstâncias relacionadas a esta análise: a comunicação dos atos processuais aos ocupantes; a legitimidade do movimento social para atuar na defesa da ocupação, e a efetividade do dever de proteção assistencial de certos grupos vulneráveis que integram a ocupação, como idosos, gestantes e, no caso desta pesquisa, as crianças.

de todos os sujeitos que forem encontrados no local, e a citação por edital daqueles que não forem encontrados (artigo 554), como também buscando assegurar a ciência de todos os ocupantes. O mesmo artigo determina a necessidade de dar publicidade à existência da ação, o que pode ser feito com publicações na imprensa, afixação de cartazes no imóvel, anúncios por meios de faixa entre outras modalidades, conforme observado na cartilha de Conflitos Possessórios Coletivos disponibilizada pelo Ministério Público do Estado de São Paulo. Em que pese todo esse arcabouço normativo para assegurar o direito dos ocupantes ao contraditório e à ampla defesa, publicidade dos atos e devido processo legal, o único processo em que ocorreu a citação por edital foi o da Ocupação Vila Paula, em março de 2020. As citações dos outros processos analisados se deram com irregularidade na individualização concreta do movimento, como no processo da Ocupação Vila Paula, mas sem citação por edital; e publicidade da existência da ação em meios de alta divulgação da região, conforme observação das defesas das ocupações. Estas imperfeições processuais são consoantes com as informações incompletas fornecidas nas petições iniciais e com o encontro de indivíduos no local da ocupação por oficial de justiça (no processo da Ocupação Itatinga, um dos sujeitos citados não era ocupante). Sobre o desenvolvimento da ação possessória sem a individualização correta dos réus, nos processos em que ocorreu defesa judicial, esta prestou as informações necessárias para individualização e identificação do movimento social mas, ainda assim, os processos tiveram andamento sem que houvesse a modificação do nome do polo passivo.

${ }^{20}$ Nesta pesquisa, a qualificação incompleta ou parcial correspondeu a 62,5\% dos processos analisados.

${ }^{21}$ Os movimentos sociais têm por definição serem sujeitos políticos. No caso dos movimentos sociais que lutam por moradia urbana, as experiências de enfrentamentos em desfavor do direito à moradia por cada indivíduo criam a identificação do movimento (ou seja, cada movimento é pautado pelas vivências dos integrantes e, assim, é único), por isso não podem ser compreendidos como iguais. Cf. MIAGUSKO, Edson. Movimentos de moradia e sem teto em São Paulo: experiências no contexto do desmanche. São Paulo: Alameda, 2012. p. 58. Apesar disso, constou a qualificação da Ocupação Vivenda-Itayu de forma errada nos autos e na descrição contida no portal eletrônico do Tribunal de Justiça de São Paulo. Essa ocupação foi nomeada como Movimento dos Trabalhadores Rurais Sem Terra (MST), mesmo não se identificando como tal, vide manifestações contidas no processo (fls. 161203). Ressalta-se que o MST tem como principal diretriz a ocupação de áreas rurais, ao passo que a área de ocupação da Vivenda Itayu é urbana, não sendo possível, a organização da Ocupação Vivenda-Itayu como pertencente ao MST. 
Conforme mencionamos, a não-individualização da ocupação foi justificada, na maior parte dos processos analisados, pela dificuldade de identificação dos ocupantes em razão de seu grande número, ou diante da própria dinâmica das invasões coletivas, que abarca a intensa rotatividade de pessoas que utilizam a ocupação como como moradia. A partir da justificativa que leva os autores das ações possessórias a não qualificar o polo passivo (ocupantes):

(...) derivam duas constatações importantes sobre as concepções que estruturam os
limites da interpretação jurisdicional sobre os conflitos fundiários urbanos e mesmo
sobre o lugar desses fenômenos no direito contemporâneo. A primeira delas refere-se
aos entraves que ainda subsistem para a tutela coletiva de direitos. O direito moderno,
como já dito, funda-se na construção de um sujeito de direito individual que, dotado
de autonomia da vontade (também individual) relaciona-se com o ordenamento
jurídico por meio do exercício de seus direitos subjetivos (...) para além disso, por
detrás do critério de factibilidade que obstaculiza a citação personalizada dos réus, há
ainda um segundo aspecto que merece cuidado. A impossibilidade de individualização
dos sujeitos em função do "caráter instável" das dinâmicas das ocupações corresponde
à leitura do espaço como uma arena desordenada que necessita da intervenção
regulatória do direito, como explicitamos no primeiro capítulo deste trabalho. As
ocupações urbanas são tomadas como espaços de caos, de anomia, de inexistência de
leis, e representadas pela descrição dos elementos que demarcam sua falta --diante da
estabilidade do registro proprietário individual.

Além disso, na pesquisa da autora acima, foi identificada outra hipótese para a falta de individualização: a generalização dos movimentos sociais de luta por moradia como iguais. ${ }^{23}$ Ao não haver a correta identificação de quem deve figurar no polo passivo da ação possessória, ocorre a despersonalização dos ocupantes e, em relação às crianças e aos demais grupos mais vulneráveis, ocorre sua invisibilização, de modo que o processo é apresentado com a aparência de que não há problemas sociais envolvidos na ação possessória, permitindo que ela tramite como se o réu fosse apenas um cidadão adulto que, por livre autonomia de sua vontade, decidiu invadir propriedade alheia.

Ressalte-se por fim, que apenas nos processos da Ocupação Vila Paula I e II ocorreu a individualização concreta do movimento social na identificação do polo passivo, que é o Movimento por Direito à Moradia (MDM). Em todos os outros processos, as ocupações por

\footnotetext{
${ }^{22}$ BONILHA, Giovana Milano. Crônicas de despejos anunciados: análise das decisões em conflitos fundiários urbanos. Rev. Direito Práxis, Rio de Janeiro, Vol. 9, N. 3, 2018, p. 1256.

${ }^{23}$ Por mais que este artigo não tenha como objetivo apresentar um estudo sobre a formação e a trajetória dos movimentos sociais de moradia, entendemos necessário ressalvar que a caracterização desses movimentos, em geral, é de construção democrática, em que o conflito evidencia para a sociedade os projetos das pessoas historicamente silenciadas pela lógica opressiva da dominação social (...). No que concerne aos movimentos por moradia, eles se inserem no cenário de confronto entre o direito à moradia e a dinâmica do mercado imobiliário. TRINDADE, Thiago Aparecido. Protesto e Democracia: Ocupações Urbanas e Luta pelo Direito à Cidade. Jundiaí: Paco Editorial, 2017.
} 
moradia urbana não foram individualizadas, mesmo após a sua defesa o requerer, deixando na qualificação apenas um ocupante ou até mesmo o termo invasores desconhecidos.

\section{ARgUMENTAÇÕES PROCESSUAIS APRESENTADAS PARA PROTEÇÃo DA CRIANÇA}

\subsection{Intimação do Ministério Público Estadual}

O Ministério Público é uma instituição que tem como principal atribuição a defesa da ordem jurídica (artigo 127 da Constituição Federal), apesar de já existir anteriormente à Constituição Federal de 1988, foi a partir dela que suas atribuições foram estabelecidas com mais independência dos poderes do Estado, para assegurar a proteção contra violações de direitos e controle dos poderes do Estado. ${ }^{24}$

No que concerne ao direito da criança, matéria legislativa concorrente aos entes da federação (artigo 24 da Constituição Federal), o Estatuto da Criança e do Adolescente (Lei Federal n. 8069/1990) institui atribuições especificas ao Ministério Público Estadual:

Art. 202. Nos processos e procedimentos em que não for parte, atuará obrigatoriamente o Ministério Público na defesa dos direitos e interesses de que cuida esta Lei, hipótese em que terá vista dos autos depois das partes, podendo juntar documentos e requerer diligências, usando os recursos cabíveis.

Apesar do disposto no Estatuto da Criança e do Adolescente (ECA) acerca da atuação do Ministério Público em relação à defesa dos direitos da criança, nos processos das Ocupações Nelson Mandela I (fls. 207) e Vila Paula II (fls. 239) o Ministério Público só foi tardiamente intimado, enquanto nas ações possessórias das Ocupações Nelson Mandela II e Itatinga, não houve qualquer intimação para que atuasse. Embora a legislação determine a nulidade de todos os atos processuais em caso de o Ministério Público não ser intimado para atuar na defesa dos interesses das crianças, e embora as defesas dos movimentos sociais tenha alegado esse fato

\footnotetext{
${ }^{24}$ Essas atribuições pertencem à instituição Ministério Público, que abrange o Ministério Público Estadual, o Federal, o do Trabalho e o Militar.
} 
tanto na contestação das Ocupações Nelson Mandela I e II quanto na da Vivenda-Itayu, a falta de intimação do Ministério Público não gerou nulidade em nenhum desses processos.

A intervenção do Ministério Público como fiscal da defesa dos direitos e garantias da criança (como nestes casos) foi entendida como devida em razão da relevância social da proteção dos direitos da criança, conforme disposto na Constituição Federal, em seu artigo 227:

É dever da família, da sociedade e do Estado assegurar à criança, ao adolescente e ao jovem, com absoluta prioridade, o direito à vida, à saúde, à alimentação, à educação, ao lazer, à profissionalização, à cultura, à dignidade, ao respeito, à liberdade e à convivência familiar e comunitária, além de colocá-los a salvo de toda forma de negligência, discriminação, exploração, violência, crueldade e opressão.

É preciso compreender, que a proteção dos direitos da criança se faz necessária por (i) estarem plenamente relacionados com o pleno desenvolvimento infantil visando ao bem-estar e sua vida na sociedade; (ii) elevado grau de dependência da criança, tornando se um grupo socialmente vulnerável e, consequentemente, mais submisso ao ambiente em que se encontra. Isso impõe uma visão diferenciada do processo, assim como uma atenção constante do Ministério Público.

Tal compreensão pertence ao sistema da Doutrina da Proteção Integral da Criança, positivado em artigo 227 da Constituição Federal, e tem como base os princípios da prioridade absoluta e do melhor interesse da criança, sujeito de direito, independente da ideia de propriedade ligada a família e a disposição de norma jurídica da proteção. Nesse sentido, destaca-se:

(...) que as ações do Poder Público, que devem sempre ter por norte, dentre outros, o princípio da legalidade (conforme art. 37, da Constituição Federal), que obviamente importa no fiel respeito aos comandos legais e, acima de tudo, constitucionais (...) se encontram juridicamente vinculadas no sentido da busca da proteção integral à criança e ao adolescente, para o que deverá ser destinada uma atenção e tratamento absolutamente prioritários, inclusive no que diz respeito ao atendimento de sua família. $^{25}$

Além disso, a necessidade da atenção constante do Ministério Público em relação à vulnerabilidade da criança decorre do dever de cumprimento, pelo Estado brasileiro, do

\footnotetext{
${ }^{25}$ MINISTÉRIO PÚBLICO DO ESTADO DO PARANÁ. Diretrizes para a Política Destinada ao Atendimento de Crianças e Adolescentes. (versão online no portal eletrônico do Ministério Público do Estado do Paraná), Brasil, jan. 2014.
} 
disposto no artigo $3^{\circ}$, item 1 da Convenção sobre os Direitos da Criança da Organização das Nações Unidas (ONU) promulgado pelo Decreto Executivo n. 99.710/1990:

Todas as ações relativas às crianças, levadas a efeito por instituições públicas ou privadas de bem estar social, tribunais, autoridades administrativas ou órgãos legislativos, devem considerar, primordialmente, o interesse maior da criança (grifamos).

No processo da Ocupação Vivenda-Itayu, em decisão inicial, o juiz intimou o Ministério Público pela obrigatoriedade de atuação em defesa dos direitos e interesses das crianças ocupantes:

Tendo em vista os indícios de que os posseiros se tratam de sem-teto e que, dentre eles, há crianças, determino que seja oficiado à Secretaria Municipal de Habitação e de cidadania, Assistência e Inclusão Social e ao Conselho Tutelar, bem como que seja intimado o Ministério Público para acompanhamento do ato reintegratório, encaminhamento dos posseiros para local adequado e tomada de providências quanto às famílias e eventuais menores em situação de risco. Expeça-se mandado, o qual deverá ser cumprido por quatro (4) oficiais de justiças, na presença representantes do Autor e das instituições acima referidas, autorizando-se uso de força policial para que $\mathrm{o}$ ato seja realizado de maneira a preservar a segurança e incolumidade física de todos os envolvidos. Expeça-se ofício ao Comando da Polícia Militar para as devidas providências. Os Srs. Oficiais de Justiça procederão, por igual, à identificação dos ocupantes, de forma a que se proceda à regularização do polo passivo da demanda (grifamos) ${ }^{26}$

Contudo, apesar da intimação do Ministério Público, conforme dispõe o ECA, foi compreendido por este que sua atuação seria acessória e supletiva à do Conselho Tutelar:

3- Ressalto que a intervenção do MP nestes autos é como fiscal da ordem jurídica, nos termos do artigo 178, III do novo Código de Processo Civil, não sendo necessária a intervenção do PJ da Infância e Juventude em qualquer ato ou termo processual, de vez que, constatada pelo Conselho Tutelar qualquer violação de direitos de crianças ou adolescentes, tal fato deverá ser comunicado diretamente para adoção das medidas cabíveis naquela esfera de atuação ministerial. ${ }^{27}$

Esta disposição da Promotoria de Justiça da Infância e Juventude, além de contrariar o texto legal mencionado, cria uma nova função e dever para o Conselho Tutelar, a de acompanhamento dos atos processuais, mesmo que, conforme o artigo 131 do Estatuto, o Conselho não possuir qualquer função jurisdicional.

\footnotetext{
${ }^{26}$ BRASIL, Tribunal de Justiça de São Paulo. Interdito Proibitório no: 1007144-98.2016.8.26.0114, 2016, p. 6566.

${ }^{27}$ SÃO PAULO. Tribunal de Justiça de São Paulo. Interdito Proibitório n.: 1007144-98.2016.8.26.0114, 2016, p. 77.
} 
Mesmo com a intimação para que realize a atribuição constitucional de fiscal da ordem jurídica, no que tange à defesa estatutária dos direitos das crianças em âmbito jurisdicional, em conformidade com dispositivo já referido, ocorre a abstenção dessa função. Além do processo da Ocupação Vivenda-Itayu, isso também ocorreu nos processos das Ocupações Nelson Mandela I e II, Itatinga Vila Paula I e II.

\subsection{O vínculo entre a moradia e os direitos fundamentais da criança}

Os Direitos Humanos são interdependentes e indivisíveis, é o que preceitua a Declaração e Programa de Ação de Viena de 1993, das Nações Unidas. Em outras palavras, a violação do direito à moradia pode afetar a efetivação de outros direitos humanos, como o contrário também.

O acesso à moradia é uma condição prévia para a efetivação de outros direitos humanos, em especial, nos casos analisados, à educação e à saúde, ${ }^{28}$ que são os direitos mais afetados das crianças pela falta de moradia. As desocupações violentas têm consequências negativas a outros direitos dos ocupantes, e em relação à criança, visto sua condição de vulnerabilidade social, a interrupção provisória ou definitiva de serviços oferecidos pelo Estado, como o acesso à educação infantil e básica e o sistema universal de saúde (SUS), o que prejudica sobremodo o desenvolvimento infantil.

A fim de entender esta característica de interdependência dos Direitos Humanos, o Fundo das Nações Unidas para a Infância (UNICEF) analisou no Brasil a relação entre a garantia dos direitos fundamentais da criança e os registrados nos serviços públicos de educação e saúde, desenvolvendo a problemática da moradia com a óbice do desempenho escolar. Como resultado desta análise, foi publicado, em 2018, o relatório Pobreza na Infância e na Adolescência no Brasil, ${ }^{29}$ com a temática de privações múltiplas de direito, ${ }^{30}$ que dispõe que os direitos mais violados são saneamento (13,3 milhões de crianças afetadas), seguido por

\footnotetext{
${ }^{28}$ A questão do direito à saúde, em especial pela necessidade de identificar as crianças ocupantes nos postos de saúde do município, não foi levantada pelas defesas.

29 FUNDO DAS NAÇÕES UNIDAS PARA A INFÂNCIA. Pobreza na Infância e na Adolescência. Portal Eletrônico do Fundo das Nações Unidas para Infância (versão online) Brasil, ago. 2018.

${ }^{30}$ A UNICEF, em seus relatórios, tem adotado o termo privações múltiplas, em que a pobreza infantil tem múltiplas dimensões, consequência da interdependência de privações, exclusão e vulnerabilidade da criança que a impede de ter desenvolvimento adequado. FUNDO DAS NAÇÕES UNIDAS PARA A INFÂNCIA, 2018, p. 7
} 
educação (8,8 milhões), água (7,6 milhões), informação (6,8 milhões), moradia (5,9 milhões) e trabalho infantil (2,5 milhões). ${ }^{31}$

Esta interdependência entre direito à moradia e direito à educação das crianças (ambos direitos humanos previstos nos artigos 11 e 13 do Pacto Internacional sobre Direitos Econômicos, Sociais e Culturais, internalizado pelo Decreto n. 591/1992), é utilizada como tese argumentativa de defesa das Ocupações para impedir o cumprimento à ordem judicial de reintegração de posse durante o ano letivo das crianças ocupantes, nos processos envolvendo as Ocupações Nelson Mandela I e II.

Destaque-se que o sistema de garantia de proteção integral da criança, introduzido pela Constituição Federal de 1988 e que tem por principal legislação o Estatuto da Criança e Adolescente, não dispõe de maneira específica sobre o direito à moradia, como ocorrer em relação ao direito à educação - que possui capitulo exclusivo (capítulo IV) e seções especiais (seção I do capítulo II) na legislação-, mas garante a moradia, ao dispor em seu artigo $3^{\circ}$, caput e parágrafo único, dever de proteção a todos os direitos fundamentais da criança:

Observa-se que a tutela constitucional e infraconstitucional asseverou o princípio da proteção integral como norte para elaboração do ordenamento jurídico voltado à tutela dos direitos e garantias fundamentais das crianças (...). ${ }^{32}$

No processo da Ocupação Nelson Mandela I, a necessidade de proteção de ambos os direitos é invocada pela Defensoria Pública Estadual de São Paulo como condição de cumprimento da ordem judicial de reintegração de posse (fls. 436). Além disso, anteriormente a esta manifestação (fls. 182), a mesma entidade, mas na figura do Centro de Atendimento Multidisciplinar Regional, já havia sinalizado aos outros atores envolvidos na lide processual quanto à presença de crianças ocupantes, por meio de levantamento por Assistência Social:

Através do levantamento do perfil verificou-se número significativo de crianças. Este dado revela o uso de serviços públicos de educação, saúde, cultura e lazer, conforme preconiza o Estatuto da Criança e do Adolescente. ${ }^{33}$

\footnotetext{
${ }^{31}$ FUNDO DAS NAÇÕES UNIDAS PARA A INFÂNCIA, 2018. p. 8.

32 BARACHO, Hertha Urquiza; BRISOLA; Anna Karla da Silva Brisola; Junior José da Silva Alves. A responsabilidade social empresarial como mecanismo à proteção integral de crianças e adolescentes. Rev. Juris Poiesis, Rio de Janeiro, vol. 22, n. 29, 2019, p. 113.

${ }^{33}$ SÃO PAULO. Tribunal de Justiça de São Paulo. Ação de Reintegração de Posse n. 1030040-38.2016.8.26.0114, p. 183, 2016.
} 
A realização do ato de desocupação estava prevista para o mês de março do ano de 2017 (ou seja, durante o ano letivo escolar), mesmo com a demonstração do perfil infantil da ocupação. E assim foi concretizado o ato reintegratório, durante período letivo, conforme previsão disposta no planejamento da Secretaria de Estado dos Negócios da Segurança Pública da Policia Militar do Estado de São Paulo, $47^{\circ}$ Batalhão de Policia Militar do Interior (fls. 410), sendo notificado da efetividade por mero expediente do juiz (fls. 450) em 30 março de 2017. ${ }^{34}$

\subsection{A proteção normativa da criança e o dever de desocupação com destino definido}

Desocupações violentas em conflitos fundiários urbanos são a realidade de quem luta pela efetivação do direito à moradia adequada no Brasil, como exemplarmente demonstra o procedimento reintegratório ocorrido em São José dos Campos, SP, no ano de 2012, em que a Ocupação Pinherinho ${ }^{35}$ sofreu duras investidas do Estado no procedimento de desocupação, acarretando violações de Direitos Humanos.

Além disso, ocupações e outros territórios populares ${ }^{36}$ na cidade são, na maioria das vezes, enquadrados como ilegais. ${ }^{37}$ Os ocupantes são tratados pelos veículos de comunicação de grande circulação ${ }^{38}$ como invasores e até mesmo criminosos. Contudo, trata-se de propriedades que não exercem a função social, em desacordo do previsto no artigo $5^{\circ}$, XXIII, da Constituição Federal.

Em que pese não termos dados quantitativos das desocupações já realizadas em relação a todo o território brasileiro, nem à região em que a pesquisa está inserida, o Observatório de

\footnotetext{
${ }^{34}$ Notícia publicada pelo portal eletrônico de notícias G1 Campinas e Região (por meio do Jornal EPTV), tem por manchete "Após reintegração de posse, centenas de famílias ainda estão desabrigadas em Campinas". Dentre as imagens contidas para elucidação, há duas imagens de crianças ocupantes, com abrigos improvisados fornecidos pelos moradores dos arredores da ocupação reintegrada. Cf. https://g1.globo.com/sp/campinasregiao/noticia/apos-reintegracao-de-posse-centenas-de-familias-do-mandela-ainda-estao-desabrigadas.ghtml.

35 Para referências da Reintegração do Pinheirinho, cf.: <https://www.cartacapital.com.br/sociedade/pm-emoradores-se-enfrentam-durante reintegração> <https://www12.senado.leg.br/noticias/materias/2012/02/23/entenda-o-caso-pinheirinho>.

${ }^{36}$ Territórios com desigualdade socio-territorial, engendradas por processos de reestruturação espaciais associados os interesses do capital, que via de regra provocam a expulsão da população pobre, alterando seu modo de vida e suas formas de sobrevivência. Tal definição é retirada das pesquisas do grupo Territórios Populares, coordenados pela LabCidade da Faculdade de Arquitetura e Urbanismo da Universidade de São Paulo (FAU-USP) e outros autores, disponível no link, cf.: <http://territoriospopulares.indisciplinar.com/>.

${ }^{37} 37$ MARICATO, Ermínia. O impasse da política urbana no Brasil. São Paulo: Editora Vozes, 2010, p. 187.

${ }^{38}$ No processo judicial das Ocupações Nelson Mandela I e prédio Padova são acostadas aos autos fotos de notícias que enquadram os movimentos como invasores e ilegais.
} 
Remoções (OR) vinculado às Universidades Federal do ABC (UFABC), Federal do Ceará (UFCE) e Federal de Minas Gerais (UFMG), como também a Faculdade de Arquitetura e Urbanismo de São Paulo (FAU-USP), realizam desde 2012 o mapeamento das remoções e ameaças de remoção na Região Metropolitana de São Paulo ${ }^{39}$ que, bienalmente, publica relatório das remoções. Do mais recente relatório disponibilizado consta informação que, entre 2017 e 2018, ocorreram 808 remoções ou ameaças de remoções, das quais 75\% foram por via de reintegração de posse, ou seja, conflito fundiário urbano. ${ }^{40}$

Os efeitos de tais atos atentam contra os direitos dos ocupantes, em especial neste trabalho, aos direitos das crianças, pois várias desocupações são realizadas com violência da força policial, resultam em famílias desabrigadas ou sem acesso aos meios para sua sobrevivência, tendo impacto sobre outros direitos humanos da criança (além da moradia), como direito à educação, à saúde e à integridade física. Dessa forma, a remoção forçada deve ser evitada em favor da proteção assistencial às crianças ocupantes, uma vez que, por serem seres humanos em processo de desenvolvimento físico e psicológico, possuem proteção jurídica diferenciada.

Tendo exposto que as remoções violentas são o cotidiano das crianças com direito à moradia violado e que são recorrentes tanto no âmbito nacional como internacional. A fim, desses procedimentos não ocorreram mais de maneira a violar direitos, a Organização das Nações Unidas, por meio de seu Comitê para os Direitos Econômicos, Sociais e Culturais, elaborou o Comentário Geral n. 7, denominado O direito à moradia/habitação adequada, com a temática despejos forçados baseado no Artigo 11, item 1 do Pacto Internacional sobre os Direitos Econômicos, Sociais e Culturais (PIDESC). Neste documento, foram estabelecidos parâmetros para o processo de desocupação sem violação de direitos, em especial o disposto no item 13 e 16 do Comentário, pois dispõe que não podem ser ignoradas as situações específicas das crianças e de outros grupos em condição de vulnerabilidade e que, esses não poderiam ficar desabrigados. As disposições do Comentário Geral n. 7, como documento internacional, bem como as do Comentário Geral n. 4 elaborado pelo mesmo Comitê, foram utilizadas como base

\footnotetext{
${ }^{39} \mathrm{O}$ observatório de Remoções analisou as remoções em 10 municípios da RMSP: São Paulo, São Bernardo do Campo, Santo André, São Caetano do Sul, Mauá, Guarulhos, Diadema, Cajamar, Cotia, Mogi das Cruzes e Itaquaquecetuba.

${ }^{40}$ LINS, Regina Dulce; ROLNIK, Raquel (orgs.). Observatório de Remoções 2017-2018: Relatório bianual. São Paulo: FAU USP, 2018, p. 21.
} 
dos argumentos de defesa das Ocupações Nelson Mandela I e II, Vila Paula I e II, e VivendaItayu.

O item 13 do Comentário Geral n. 7 dispõe que, para evitar o uso de força no ato de desocupação, é necessário que as autoridades públicas explorem todas as alternativas, em conjunto com as pessoas a serem removidas, principalmente quando estas são numerosas. ${ }^{41}$ Já seu item 16 declara que as desocupações não devem acontecer antes de se identificarem novo local de moradia para as pessoas removidas, tampouco que a remoção ocorra mediante a violação de quaisquer direitos humanos dos removidos, cabendo ao Poder Público utilizar de todas as medidas cabíveis, no máximo da sua eficiência, para assegurar tais medidas de proteção. $^{42}$

Além destes Comentários Gerais no Comitê das Nações Unidas, a Relatoria Especial da ONU para a moradia adequada sintetizou, em documento oficial, ${ }^{43}$ o que as normas internacionais determinam sobre remoções involuntárias decorrentes de projetos públicos e privados de infraestrutura e urbanização, isto é, atos praticados contra a vontade das pessoas que habitam determinado espaço, envolvendo força ou coação, com base em sentença judicial ou não, fornecendo amparo também as situações de remoção por conflitos fundiários urbanos, envolvendo ocupações, como nos processos analisados. Assim, foi disposto que os atos de remoções forçadas não devem:

(i) Fazer uso da violência e da intimidação, em nenhuma circunstância; (ii) Ser realizada de forma discriminatória ou replicar padrões discriminatórios; (iii) Resultar em pessoas e famílias desabrigadas; (iv) Usar a demolição das casas ou das lavouras como retaliação ou ameaça contra a população;(v) Destruir os bens das famílias afetadas; (vi) Ignorar a situação específica de mulheres e grupos em condição de vulnerabilidade (idosos e crianças, assim como outros) (grifamos) ${ }^{44}$

\footnotetext{
41 "States parties shall ensure, prior to carrying out any evictions, and particularly those involving large groups, that all feasible alternatives are explored in consultation with the affected persons, with a view to avoiding, or at least minimizing, the need to use force. Legal remedies or procedures should be provided to those who are affected by eviction orders. States parties shall also see to it that all the individuals concerned have a right to adequate compensation for any property, both personal and real, which is affected. In this respect, it is pertinent to recall article 2.3 of the International Covenant on Civil and Political Rights, which requires States parties to ensure "an effective remedy' for persons whose rights have been violated and the obligation upon the 'competent authorities (to) enforce such remedies when granted."

42 "Evictions should not result in individuals being rendered homeless or vulnerable to the violation of other human rights. Where those affected are unable to provide for themselves, the State party must take all appropriate measures, to the maximum of its available resources, to ensure that adequate alternative housing, resettlement or access to productive land, as the case may be, is available."

${ }^{43}$ ORGANIZAÇÕES DAS NAÇÕES UNIDAS. Como atuar em projetos que envolvem despejos e remoções? Portal eletrônico da relatoria especial para moradia adequada (versão online), Brasil, ago.2010, p. 21.

${ }^{44}$ ORGANIZAÇÃO DAS NAÇÕES UNIDAS, 2010, p. 7.
} 
Dessa forma, importaria aos movimentos sociais demostrarem a existência de crianças para que não ocorresse o ato reintegratório das ocupações até definição de destino para elas e outros grupos considerados vulneráveis socialmente. Observando a situação de vulnerabilidade específica das crianças, em consonância com a garantia de prioridade a proteção (artigo $4^{\circ}$, parágrafo único, alínea a, do Estatuto da Criança e do Adolescente), em que a falta de local de moradia proporciona consequências negativas no desenvolvimento infantil e que, portanto, deve ser compreendido como violação de seus direitos. Ainda mais numa situação em que a medida judicial do ato reintegratório as remove de seus lares é uma medida de proteção de uma propriedade privada que não exercia sua função social. Ou seja, a remoção ocorre para proteger a propriedade, sem preocupação com as consequências sociais do ato de reintegração, algo totalmente contrário às normativas de proteção à criança e ao adolescente.

Tanto o evidenciar a existência de crianças na Ocupação, quanto o observar as normas de proteção integral à criança e das possíveis violações de seus direitos ao serem removidas foram afirmados na peça fundamental de defesa do polo passivo (contestação), conforme tabela 1.

A tabela 1 apresenta as alegações feitas pelas defesas das Ocupações Nelson Mandela I e II, Vila Paula I e II, e Vivenda-Itayu, e as respectivas decisões judiciais.

De acordo com a tabela referida, foram utilizados argumentos semelhantes para proteção da criança, quais sejam, (1) evidência de crianças na ocupação, disposto em todas as contestações analisadas; (2) a vulnerabilidade infantil com utilização da normativa do Sistema de Proteção Integral à Criança; (3) violações de direitos provocada por um possível cumprimento de ordem de reintegração de posse; e (4) os meios necessários para o cumprimento da ordem de reintegração de posse, dispostos nas defesas das Ocupações Nelson Mandela I e II, Vila Paula II e Vivenda-Itayu.

Sobre o conteúdo dos argumentos, os itens (1) e (3) são argumentos não apresentados em tópico especifico nas contestações, pois o primeiro é a identificação quantitativa da menção do termo crianças durante as alegações de fato e de direito, e o segundo é disposto no tópico específico apresentado no mérito, dos meios necessários para o cumprimento do mandado de 
reintegração de posse $e^{45}$ que também abarca o item (4), pelo qual se afirmou que a reintegração de posse não deve ser realizada sem:

(...) consideração a quantidade de vidas e de interesses envolvidos, além da quantidade de crianças, adolescentes e idosos envolvidos, no mínimo, como medida de bom senso, de respeito à integridade física e moral e de respeito às cláusulas pétreas da nossa Carta Magna $(. . .)^{46}$ (grifamos).

Já o item (2), além de ser apresentado em tópico específico no mérito, intitulado da proteção integral à criança, ao adolescentes e ao idoso e demais vulneráveis (cadeirantes, gestantes, doentes etc.), dispõem os pontos: (i) desenvolvimento da doutrina de proteção integral da criança com a utilização da normativa jurídica; (ii) análise da criança ocupante como sujeito de direito e não como mero objeto; (iii) o Estatuto da Criança e do Adolescente e do princípio constitucional do melhor interesse da criança, e (iv) alegação da nulidade diante da falta de intervenção do Ministério Público Estadual.

Quadro 1 - Disposição simplificada da relação entre o conteúdo das defesas judiciais em formato de contestação pelas Ocupações Nelson Mandela I e II; Vila Paula I e II; e Vivenda-Itayu, e os atos do juiz.

\begin{tabular}{|c|c|c|c|c|c|}
\hline Ocupação & $\begin{array}{c}\text { Nelson } \\
\text { Mandela I }\end{array}$ & $\begin{array}{c}\text { Nelson } \\
\text { Mandela II }\end{array}$ & Vila Paula I & Vila Paula II & Vivenda-Itayu \\
\hline $\begin{array}{c}\text { Foi } \\
\text { concedida } \\
\text { liminar no } \\
\text { início do } \\
\text { processo? }\end{array}$ & Sim & Não & Sim & Sim & Sim \\
\hline $\begin{array}{c}\text { Foi } \\
\text { interposto } \\
\text { agravo de } \\
\text { instrumento } \\
\text { contra } \\
\text { decisão que } \\
\text { concedeu } \\
\text { liminar? }\end{array}$ & Sim & Não aplicável & Não & Sim & Sim \\
\hline $\begin{array}{l}\text { Argumentos } \\
\text { alegados em } \\
\text { contestação }\end{array}$ & $\begin{array}{l}\text { (1) Evidência de } \\
\text { crianças na } \\
\text { ocupação: o } \\
\text { termo criança } \\
\text { aparece } 17 \text { vezes } \\
\text { no documento; }\end{array}$ & $\begin{array}{l}\text { (1) Evidência de } \\
\text { crianças na } \\
\text { ocupação: o } \\
\text { termo criança } \\
\text { aparece } 23 \\
\text { vezes no } \\
\text { documento; }\end{array}$ & $\begin{array}{l}\text { (1) Evidência } \\
\text { de crianças na } \\
\text { ocupação: o } \\
\text { termo criança } \\
\text { aparece } 2 \\
\text { vezes no } \\
\text { documento. }\end{array}$ & $\begin{array}{l}\text { 1) Evidência de } \\
\text { crianças na } \\
\text { ocupação: o } \\
\text { termo criança } \\
\text { aparece } 12 \\
\text { vezes no } \\
\text { documento; }\end{array}$ & $\begin{array}{l}\text { (1) Evidência de } \\
\text { crianças na } \\
\text { ocupação: o } \\
\text { termo criança } \\
\text { aparece } 12 \\
\text { vezes no } \\
\text { documento; }\end{array}$ \\
\hline
\end{tabular}

\footnotetext{
${ }^{45}$ Título retirado das peças de defesa (contestação) apresentadas dos processos judiciais envolvendo as Ocupações Nelson Mandela I e II, Vila Paula II e Vivenda-Itayu, nas páginas 40, 323, 150 e 192, respectivamente.

${ }^{46}$ SÃO PAULO. Tribunal de Justiça de São Paulo. Ação de Reintegração de Posse n. 1002684-27.2017.8.26.0084, p. $322,2017$.
} 


\begin{tabular}{|c|c|c|c|c|c|}
\hline & $\begin{array}{l}\text { (2) Possui tópico } \\
\text { específico } \\
\text { acerca da } \\
\text { vulnerabilidade } \\
\text { infantil; } \\
\text { (3) Discorre } \\
\text { sobre a violação } \\
\text { de direitos } \\
\text { provocada pelo } \\
\text { cumprimento da } \\
\text { liminar de } \\
\text { reintegração de } \\
\text { posse; } \\
\text { (4) Possui tópico } \\
\text { específico } \\
\text { acerca dos } \\
\text { meios } \\
\text { necessários para } \\
\text { o cumprimento } \\
\text { da liminar de } \\
\text { reintegração de } \\
\text { posse (cita as } \\
\text { hipóteses } \\
\text { dispostas no } \\
\text { Comentário } \\
\text { Geral n.7, como } \\
\text { por exemplo, } \\
\text { área provisória } \\
\text { para as } \\
\text { famílias): } \\
\text { Informa que o } \\
\text { mandado } \\
\text { liminar de } \\
\text { desocupação } \\
\text { não determinou } \\
\text { prazo para saída } \\
\text { voluntária, e a } \\
\text { falta desse prazo } \\
\text { confronta a } \\
\text { proteção da } \\
\text { criança }\end{array}$ & $\begin{array}{c}\text { (2) Possui } \\
\text { tópico } \\
\text { especifico } \\
\text { acerca da } \\
\text { vulnerabilidade } \\
\text { infantil; } \\
\text { (3) Discorre } \\
\text { sobre a violação } \\
\text { de direitos } \\
\text { provocada pelo } \\
\text { cumprimento da } \\
\text { liminar; } \\
\text { (4) Possui } \\
\text { tópico } \\
\text { específico } \\
\text { acerca dos } \\
\text { meios } \\
\text { necessários para } \\
\text { o cumprimento } \\
\text { da liminar. }\end{array}$ & & $\begin{array}{c}\text { (2) Possui } \\
\text { tópico } \\
\text { específico } \\
\text { acerca da } \\
\text { vulnerabilidade } \\
\text { infantil; } \\
\text { (3) Discorre } \\
\text { sobre a violação } \\
\text { de direitos } \\
\text { provocada pelo } \\
\text { cumprimento da } \\
\text { liminar; } \\
\text { (4) Possui } \\
\text { tópico } \\
\text { específico } \\
\text { acerca dos } \\
\text { meios } \\
\text { necessários para } \\
\text { o cumprimento } \\
\text { da liminar. }\end{array}$ & $\begin{array}{c}\text { (2) Possui } \\
\text { tópico } \\
\text { específico } \\
\text { acerca da } \\
\text { vulnerabilidade } \\
\text { infantil; } \\
\text { (3) Discorre } \\
\text { sobre violação } \\
\text { de direitos } \\
\text { provocada pelo } \\
\text { cumprimento da } \\
\text { liminar; } \\
\text { (4) Possui } \\
\text { tópico } \\
\text { específico } \\
\text { acerca dos } \\
\text { meios } \\
\text { necessários para } \\
\text { o cumprimento } \\
\text { da liminar. }\end{array}$ \\
\hline $\begin{array}{l}\text { Houve } \\
\text { réplica? }\end{array}$ & Sim & Sim & Sim & Sim & Sim \\
\hline $\begin{array}{c}\text { Determinaçõ } \\
\text { es do juiz }\end{array}$ & $\begin{array}{c}\text { Mantém a } \\
\text { liminar e dispõe } \\
\text { a desocupação } \\
\text { voluntária em } 48 \\
\text { horas a partir da } \\
\text { intimação dos } \\
\text { advogados da } \\
\text { Ocupação; }\end{array}$ & $\begin{array}{c}\text { Oficia e intima a } \\
\text { COHAB e a } \\
\text { SEHAB, e } \\
\text { intima as partes } \\
\text { para audiência } \\
\text { de tentativa de } \\
\text { conciliação. }\end{array}$ & $\begin{array}{c}\text { Não se } \\
\text { manifesta } \\
\text { sobre os } \\
\text { pedidos } \\
\text { realizados na } \\
\text { contestação. }\end{array}$ & $\begin{array}{c}\text { Manifestação } \\
\text { apenas sobre o } \\
\text { pedido de } \\
\text { designação de } \\
\text { tentativa de } \\
\text { conciliação; } \\
\text { Designa } \\
\text { audiência de }\end{array}$ & $\begin{array}{c}\text { Mantém a } \\
\text { liminar de } \\
\text { reintegração de } \\
\text { posse; } \\
\text { (4) Não se } \\
\text { manifesta sobre } \\
\text { os pedidos } \\
\text { relacionados ao } \\
\text { tópico }\end{array}$ \\
\hline
\end{tabular}




\begin{tabular}{|c|c|c|c|c|c|}
\hline & $\begin{array}{l}\text { (4) Não se } \\
\text { manifesta sobre } \\
\text { os pedidos } \\
\text { relacionados no } \\
\text { tópico do meio } \\
\text { necessário ao } \\
\text { cumprimento da } \\
\text { liminar. }\end{array}$ & & & $\begin{array}{c}\text { tentativa de } \\
\text { conciliação; } \\
\text { Intima o } \\
\text { Ministério } \\
\text { Público para se } \\
\text { manifestar; } \\
\text { Ciência ao polo } \\
\text { ativo da } \\
\text { contestação. }\end{array}$ & $\begin{array}{c}\text { especifico dos } \\
\text { meio necessário } \\
\text { ao cumprimento } \\
\text { da liminar. }\end{array}$ \\
\hline $\begin{array}{l}\text { Disposições } \\
\text { da sentença }\end{array}$ & $\begin{array}{c}\text { Admitiu a } \\
\text { identificação } \\
\text { genérica do } \\
\text { movimento; } \\
\text { Não se } \\
\text { manifestou } \\
\text { sobre outras } \\
\text { alegações, além } \\
\text { da discussão da } \\
\text { posse; } \\
\text { Julgou } \\
\text { procedente os } \\
\text { pedidos da } \\
\text { inicial. }\end{array}$ & $\begin{array}{l}\text { Não tem } \\
\text { sentença. }\end{array}$ & $\begin{array}{l}\text { Não tem } \\
\text { sentença. }\end{array}$ & $\begin{array}{l}\text { Não tem } \\
\text { sentença. }\end{array}$ & $\begin{array}{l}\text { Não tem } \\
\text { sentença. }\end{array}$ \\
\hline
\end{tabular}

Fonte: Tribunal de Justiça de São Paulo - TJSP, 2014-2018. Elaboração: pela autora (2020).

Quanto à Ocupação Nelson Mandela II, conforme consta dos autos, é desenvolvimento consecutivo da reintegração de posse havida na Ocupação Nelson Mandela I, em que cerca de 600 famílias foram removidas, incluindo 282 crianças ( 65 bebês com até um ano, 30 crianças menores de dois anos e 187 crianças de dois a dez anos), 141 adolescentes, 28 gestantes, 24 idosos, 05 cadeirantes e demais adultos. ${ }^{47}$ Assim, estas pessoas já haviam sofrido com uma desocupação violenta (desumana) e estão em iminente risco de terem seus direitos novamente violados, com outro ato de desocupação idêntico, pois o Poder Judiciário não considerou o direito fundamental, social e humano à moradia, bem como o dever de conferir proteção diferenciada às crianças tanto no curso da instrução processual, quanto no cumprimento da ordem judicial de remoção:

Após a trágica reintegração de posse sofrida na ocupação anterior, as famílias foram abandonadas pelo poder público, chegando a perambular por até três dias nas ruas do

\footnotetext{
${ }^{47}$ Esses dados foram retirados dos estudos sociais desenvolvidos durante o andamento do processo da Ocupação Nelson Mandela I elaborado por equipe Multidisciplinar de Assistência Social, da Defensoria Pública Estadual de São Paulo.
} 
entorno da antiga ocupação, com crianças e móveis, por falta de lugar para se abrigarem. No ato da reintegração de posse, os órgãos municipais se negaram a fornecer até mesmo um ginásio solicitado pelos despejados, comprovando a crueldade dispensada a estas famílias. Os únicos espaços disponibilizados para abrigamento foram cedidos por outros movimentos de moradia como a Vila Soma, em Sumaré e o Joana Darc, em Campinas. Assim, cerca de 200 famílias, que não tinham nenhuma outra opção de abrigo, ficaram em um galpão improvisado no Joana Darc, em moradia coletiva esperando uma alternativa de moradia digna. Estas são as famílias que não tiveram nenhuma alternativa de abrigamento na cidade, sendo que as demais conseguiram algum canto para sair da rua, ainda que precariamente. Com o passar do tempo no abrigo coletivo do Joana Darc, a situação ficou insustentável no barracão e estas famílias decidiram ocupar outras terras abandonadas ou subutilizadas no Município, exigindo que se cumpra o direito de moradia assegurado constitucionalmente. Dentre muitas áreas abandonadas em Campinas, o terreno objeto da presente ação foi escolhido pelas famílias da Comunidade Nelson Mandela por estar abandonado e sequer possuir cerca na sua entrada, motivo pelo qual foi ocupado pacificamente pelas famílias. ${ }^{48}$

Por causa de toda essa situação social, o juiz, após o recebimento da petição inicial, designou audiência de justificação com realização de vistoria no imóvel ocupado, antes da citação da Ocupação e assim da apresentação da contestação. Nesta visita, contatou diversos ocupantes durante o ato, qualificando-os pelo nome, sobrenome e outras características, como casal; bem como seu núcleo familiar, destacando quais núcleos eram compostos por crianças. Ainda:

Ficou acertado que, por ora, não haverá concessão de liminar, o que será revisto pelo Juízo na hipótese de novas pessoas engrossarem a ocupação. Bem por isso, como já acima registrado, deverá ser entregue ao Juízo no dia 08/05 relatório completo de todos os ocupantes, agendando-se, desde já, nova vistoria para o dia 13/05/2017, sábado, à mesma hora. O Juízo, também informou aos ocupantes de como se dá o trâmite processual e quais são as consequências para eles de uma eventual concessão de liminar ou de decisão judicial final que lhe seja adversa, daí a exorta-los a não inovarem mais na área ocupada. O Juízo esclareceu quanto a eventual possibilidade da procedência ou improcedência dos pedidos iniciais e, se possível, os esforços serem dirigidos à via consensual. Nesse sentido, cogitou-se da possibilidade de uma negociação entre as partes para transação da área efetivamente ocupada ( grifamos). ${ }^{49}$

Posteriormente, foram juntados aos autos, conforme pedido do juiz em reunião com representante da COHAB (Companhia de Habitação Popular de Campinas), SEHAB (Secretária de Habitação do Município de Campinas), (i) relatório das famílias cadastradas na Ocupação Mandela I (fls. 230-233); (ii) estudo social da Ocupação Nelson Mandela I (fls. 363373), elaborado em fevereiro de 2017 por equipe Multidisciplinar de Assistência Social, da Defensoria Pública Estadual de São Paulo e (iii) questionário (fls.256-258) realizado pela

\footnotetext{
${ }^{48}$ SÃO PAULO. Tribunal de Justiça de São Paulo. Reintegração de Posse n. 1002684-27.2017.8.26.0084, 2017, p.287.

${ }^{49}$ SÃO PAULO. Tribunal de Justiça de São Paulo. Reintegração de Posse n. 1002684-27.2017.8.26.0084, 2017, p. 224.
} 
Comissão de Direitos Humanos da OAB-Campinas (Ordem dos Advogados do Brasil da subseção de Campinas) requerendo providências à Secretaria de Habitação municipal, em razão da vulnerabilidade social da Ocupação Nelson Mandela após a ter sofrido reintegração de posse. Tais documentos indicam a vulnerabilidade social da ocupação e, assim, o necessário dever estatal de proteção a ser garantida às crianças e a outros grupos da Ocupação.

Compreendemos que foram esses elementos que moldaram a tese argumentativa e possibilitaram o andamento processual diferente, que resultou em acordo judicial (fls. 688) entre a Ocupação, o proprietário e a Secretaria Municipal de Habitação de Campinas, intermediado pelo juiz, com prazo para desocupação da área em 31 de agosto de 2020.

\section{OS RECURSOS CÍVEIS: DEFESA INTEGRAL DA CRIANÇA E O ANDAMENTO PROCESSUAL NOS TERMOS DO CÓDIGO DE PROCESSO CIVIL}

As Ocupações Nelson Mandela I, Vila Paula II, Movimento Comunidade da Família por Moradia e Vivenda-Itayu recorreram das decisões judiciais por meio de Agravo de Instrumento, Embargos de Declaração, Agravo Regimental e Mandado de Segurança. Foram analisados 8 recursos interpostos pelas Ocupações, sendo 5 agravos de instrumentos, das Ocupações Nelson Mandela I, Vila Paula II, Movimento Comunidade da Família por Moradia e Vivenda Itayu; 1 Embargo de Declaração da Ocupação Vivenda-Itayu; 1 Agravo Regimental da Ocupação Movimento Comunidade da Família por Moradia; e 1 Mandado de Segurança da Ocupação Nelson Mandela I.

Independentemente dos requisitos de admissibilidade dos recursos cíveis, as defesas destas Ocupações utilizaram recursos a fim de suspender os efeitos das liminares de reintegração de posse concedidas, em contraposição às decisões interlocutórias (liminares) de reintegração proferidas pelos juízes, especialmente em razão de os autores das ações possessórias não terem comprovado seu direito de propriedade ou a posse efetiva dos imóveis (prova esta que é condição para pleitearem a posse dos imóveis ocupados); da possibilidade de defesa da ocupação e tempo hábil para desocupação voluntária, de modo que nenhum ocupante tivesse seus direitos violados, em especial as crianças; da não-caracterização de esbulho, pela 
falta de exercício da função social da propriedade, e da situação social em que o direito à moradia é sistematicamente negado à população de baixa renda. Contudo, nem estas questões, tampouco as alegações em favor da proteção integral da criança ocupante, foram consideradas em quaisquer decisões judiciais proferidas pelos juízes de primeira instância ou pelo Tribunal de Justiça. A justificativa foi praticamente a mesma em todas as decisões havidas até a conclusão desta pesquisa, e pode ser sintetizada pela consideração abaixo, transcrita do relatório do voto do relator, Desembargador Mendes Pereira, da $15^{\text {a }}$ Câmara de Direito Privado do Tribunal de Justiça de São Paulo, no acórdão que manteve a ordem judicial de reintegração de posse contra a Ocupação Movimento Comunidade da Família por Moradia:

\begin{abstract}
Mesmo o prazo de 120 dias para desocupação é inadmissível, posto que a norma de regência é clara no sentido de que a retomada pelo possuidor é imediata, tanto que previsto o rito especial para as ações possessórias, justamente para evitar que apossamentos indevidos se perpetuem no tempo. Por fim, não se trata de questão inerente à sensibilidade do julgador. Se não há o respeito à Lei e se permite que os próprios interessados ajam de mão própria, instaura-se a anarquia, com violação dos direitos fundamentais de todos, que sofrem por negação de Justiça. ${ }^{50}$
\end{abstract}

Quanto ao Agravo de Instrumento n. 2257385-29.2016.8.26.0000 e o Mandado de Segurança n. 2051591-74.2017.8.26.0000, ambos da Ocupação Nelson Mandela I, não foram analisados, pois a Ocupação já tinha sido removida antes da data prevista para seus julgamentos (foram extintos por perda de objeto). Em relação aos outros agravos de instrumentos interpostos pelas Ocupações, todos tiveram em acordão proferido, provimento negado, por compreensão da presença dos requisitos para concessão liminar de reintegração de posse, e o agravo regimental interposto pela Ocupação Movimento Comunidade da Família por Moradia, não foi reconhecido.

Por fim, cabe mencionar a situação atual dos processos. A ação possessória envolvendo a Ocupação Nelson Mandela I foi extinta, por sentença que julgou procedente o pedido de reintegração, proferida em 10 de maio de 2018. Em que pese, a sentença proferida ser de 2018, a Ocupação foi removida por ato reintegratório em março de $2017^{51}$. Desdobramento da reintegração de posse no Nelson Mandela I, o processo da Ocupação Nelson Mandela II está

\footnotetext{
${ }^{50}$ SÃO PAULO. Tribunal de Justiça de São Paulo. 15a Câmara de Direito Privado. Agravo de Instrumento n. 2008424-07.2017.8.26.0000, 2017, p. 271.
} 
suspenso por acordo extrajudicial homologado judicialmente. ${ }^{52}$, prorrogado novamente em 06 de março de 2020, com prazo de desocupação para 31 de agosto de 2020.

O processo da Ocupação Vivenda-Itayu também está suspenso, ao aguardo de decisão judicial. ${ }^{53}$

O processo da Ocupação Vila Paula I tem como último andamento processual (em 31 de março de 2020) a certidão de publicação de edital para citação da Ocupação (p. 290), considerando que, inicialmente, apenas alguns ocupantes foram citados pessoalmente. ${ }^{54}$

A Ocupação Vila Paula II tem como última movimentação decisão judicial de 06 de abril 2020, que deferiu suspensão processual por 6 meses a partir daquela data, por pedido da Prefeitura Municipal de Campinas, proprietária do imóvel, para elaboração de diagnóstico jurídico, urbanístico, social e ambiental do lote em que área ocupada se encontra, conforme informativo da Secretaria de Habitação e da Coordenação Técnica de Regularização Fundiária do município.

No processo da Ocupação do Prédio Padova, foi requisitado pelo juiz manifestação do Ministério Público Estadual, em relação à pedido do proprietário, que requereu intimações da Prefeitura Municipal de Campinas para se manifestar sobre a situação de uma das ocupantes, bem como do Corpo de Bombeiros para avaliação da estrutura do prédio ocupado e das condições de habitação.

\footnotetext{
52 (a) o início da retirada da ocupação deve ocorrer antes de 30/01/2020. (b) não aumentar o número de invasores e que sejam mantidas as 108 famílias, preservando-se o congelamento então determinado quando da audiência de fls. 201/202.b(c) a remoção dentro desse prazo de 12 meses independentemente da regularidade jurídica e viabilidade técnica da aprovação do loteamento pretendido, inclusive das pessoas que não tenham aderido ao programa de comprado lote, sob pena de multa igual a $\mathrm{R} \$ 500,00$ por dia de descumprimento.(d) Registro no sentido de que a área em que os ocupantes terão a opção de aquisição será aquela mencionada pelo Dr. Marcelo Ferreira da Silva, nesta oportunidade, representando a Secretaria da Habitação do Município de Campinas. (e) os autores não arcarão com os custos do desembaraço da área, quer seja: transporte de material, pessoas e animais.(e) desistência de qualquer tipo de recurso de ambas as partes. SÃO PAULO. Tribunal de Justiça de São Paulo. Reintegração de posse n. 002684-27.2017.8.26.0084, 2017, p. 681.

${ }^{53} \mathrm{O}$ proprietário da área ocupada pediu ao Judiciário para que o processo de reintegração de posse ficasse suspenso ao aguardo de decisão de mérito em Reclamação n. 2269185-83.2019.8.26.0000, ainda sem decisão até o encerramento desta pesquisa, SÃO PAULO. Tribunal de Justiça de São Paulo. 13a Câmara de Direito Privado. Agravo de Instrumento n. 2144884-30.2019.8.26.0000, 2019, p. 40.

${ }^{54} \mathrm{O}$ procedimento ocorre de acordo com o artigo 554, parágrafo $1^{\circ}$ do Código de Processo Civil, que determina: “\$ $1^{\circ}$ No caso de ação possessória em que figure no polo passivo grande número de pessoas, serão feitas a citação pessoal dos ocupantes que forem encontrados no local e a citação por edital dos demais, determinando-se, ainda, a intimação do Ministério Público e, se envolver pessoas em situação de hipossuficiência econômica, da Defensoria Pública."
} 
Os autos da Ocupação Itatinga foram arquivados definitivamente em 24 de outubro de 2019, resultado do trânsito em julgado da sentença que determinou a reintegração de posse, expedindo "mandado de intimação para desocupação voluntária, no período de 30 dias, sob pena de reintegração forçada, inclusive com força polícia, desde já autorizada". ${ }^{55}$ Como não ocorreu a desocupação voluntária, foi dado início a cumprimento de sentença, com novo número de processo n. 0002545-24.2019.8.26.0084 que, possui como última movimentação (18 de maio de 2020), requisição do juiz para devolução do mandado expedido de intimação.

\section{CONCLUSÃO}

Procuramos, ao longo desta análise de ações possessórias, identificar a estratégia de defesa dos movimentos sociais de luta por moradia, entender seus argumentos e identificar se a normativa nacional e internacional de garantia e proteção diferenciada às crianças teria sido utilizada em favor das crianças ocupantes, e se o Poder Judiciário considerou tal normativa em suas decisões. Esse sistema normativo de proteção à criança ocupante é formado não apenas pelo artigo 227 da Constituição Federal e pelo Estatuto da Criança e do Adolescente, mas também pelos Comentários Gerais n. 4 e n. 7 do Comitê das Nações Unidas sobre Diretos Econômicos, Sociais e Culturais; pelo Pacto Internacional sobre Direitos Econômicos, Sociais e Culturais, e pela Resolução n. 10, de 17 de outubro de 2018, publicado pelo Conselho Nacional dos Direitos Humanos.

Visto que o sistema de proteção integral da criança, estabelecido pela doutrina da proteção integral, é formado por normas jurídicas cogentes e de ordem pública, sua aplicação poderia ocorrer de ofício pelo Poder Judiciário, isto é, aplicadas mesmo se não tivessem sido alegadas pela defesa ou pelo Ministério Público. Por este motivo, esperávamos encontrar a aplicação desse sistema de garantia dos direitos fundamentais à criança em todos os conflitos possessórios envolvendo ocupações de movimentos sociais de luta por moradia.

${ }^{55}$ S̃̃O PAULO. Tribunal de Justiça de São Paulo. Reintegração de Posse n. 0000178-66.2015.8.26.0084, 2015. 
Assim, foi verificado que a normativa nacional e internacional foi utilizada em favor da proteção ao desenvolvimento infantil e à garantia do direitos fundamentais às crianças ocupantes, nos processos das Ocupações Nelson Mandela I e II, Vila Paula I e II, VivendaItayu e Movimento Comunidade da Família por Moradia, ${ }^{56}$ alegadas nas contestações e suscitadas nos recursos cíveis interpostos pelos movimentos, mas não foi considerada nos atos decisórios dos juízes

Em que pese a existência e a validade deste arcabouço normativo para proteção das crianças ocupantes, ao menos nos processos aqui analisados, as decisões judiciais não o levaram em conta e promoveram o andamento das ações possessórias sem preocupação com o direito dos grupos socialmente vulneráveis.

\section{REFERÊNCIAS BIBLIOGRÁFICAS}

\section{INSTRUMENTOS NORMATIVOS}

BRASIL. [Constituição (1988)]. Constituição da República Federativa do Brasil de 1988. Brasília, DF: Presidência da República [2016]. Disponível em: http://www.planalto.gov.br/ccivil_03/constituicao/constituicao.htm. Acesso em: 08 de jun. 2020.

Decreto $n^{\circ}$ 99.710, de 21 de setembro 1990. Promulga a Convenção sobre os Direitos da Criança. In: Diário Oficial da República Federativa do Brasil, Brasília, DF, 22 de set. 1990. Disponível em:http://www.planalto.gov.br/ccivil_03/decreto/1990-1994/d99710.htm. Acesso em: 08 de jun. 2020.

Decreto $n^{o}$ 591, de 6 de julho de 1992. Atos internacionais. Pacto Internacional sobre Direitos Econômicos, Sociais e Culturais. Promulgação. In: Diário Oficial da República Federativa do Brasil, Brasília, DF, 06 de jul. 1992. Disponível em: http://www.planalto.gov.br/ccivil_03/decreto/1990-1994/d0591.htm. Acesso em: 08 de jun. 2020.

Lei federal $n^{\circ}$ 8.069, de 13 de julho de 1990. Dispõe sobre o Estatuto da Criança e do Adolescente e dá outras providências. In: Diário Oficial da República Federativa do Brasil, Brasília, DF, 16 jul. 1990. Disponível em: http://www.planalto.gov.br/ccivil_03/leis/18069.htm. Acesso em: 08 de jun. 2020.

\footnotetext{
${ }^{56}$ Como dito na introdução, a ação possessória desta Ocupação tramita em segredo de justiça, nos termos da Resolução 121 do Conselho Nacional de Justiça.
} 
Lei $n^{o}$ 10.406, de 10 de janeiro de 2002. Institui o Código Civil: In: Diário Oficial da República Federativa, Brasília, DF, 11 jan. 2002. Disponível em: http://www.planalto.gov.br/ccivil_03/leis/2002/110406.htm. Acesso em: 08 de jun. 2020.

Lei $n^{o} 13.105$, de 16 de março de 2015. Código de Processo Civil. In: Diário Oficial da República Federativa do Brasil, Brasília, DF, 17 mar. 2015. Disponível em: http://www.planalto.gov.br/ccivil_03/_ato2015-2018/2015/lei/113105.htm. Acesso em: 08 jun. 2020.

Ministério dos Direitos Humanos. Conselho Nacional dos Direitos Humanos. Resolução $n^{\circ} 10$ de 17 de outubro de 2018. Dispõe sobre soluções garantidoras de direitos humanos e medidas preventivas em situações de conflitos fundiários coletivos rurais e urbanos. Disponível em: https://www.gov.br/mdh/pt-br/assuntos/noticias/todas-asnoticias/2018/outubro/resolucao-para-garantia-de-direitos-humanos-em-situacoes-deconflitos-por-terra-e-aprovada-pelo-conselho-nacional-dos-direitos-

humanos/copy_of_Resoluon10Resoluosobreconflitospossessriosruraiseurbanos.pdf. Acesso em: 08 jun. 2020.

Conselho Nacional de Justiça. Resolução $n^{\circ} 121$ de 5 de outubro de 2010. Dispõe sobre a divulgação de dados processuais eletrônicos na rede mundial de computadores, expedição de certidões judiciais e dá outras providências. In: Diário Oficial da República Federativa do Brasil, Brasília, DF, 11 out. 2010. Disponível em: https://atos.cnj.jus.br/atos/detalhar/atos-normativos?documento=92. Acesso em: 08 de jun. 2020.

Ministério das Cidades. Conselho Nacional das Cidades. Resolução Recomendada $n^{o}$ 87 de 8 de dezembro de 2009. Recomenda ao Ministério das Cidades instituir a Política Nacional de Prevenção e Mediação de Conflitos Fundiários Urbanos. In: Diário Oficial da Republica Federativo do Brasil, Brasília, DF, 25 mai. 2010. Disponível em: http://www.lex.com.br/doc_6220511_RESOLUCAO_RECOMENDADA_N_87_DE_8_DE_ DEZEMBRO_DE_2009.aspx. Acesso em: 08 de jun. 2020.

Lei Complementar $n^{o} 189$ de 8 de janeiro de 2018. Dispõe sobre o Plano Diretor Estratégico do Município de Campinas. In: Diário Oficial da Prefeitura Municipal de Campinas, Campinas, SP, 92018.2 jan. 2 Disponível http://suplementos.campinas.sp.gov.br/admin/download/suplemento_2018-0109_cod473_1.pdf. Acesso em: 08 jun. 2020.

\section{PROCESSOS ANALISADOS}

SÃO PAULO. Tribunal de Justiça de São Paulo, $13^{a}$ Câmara de Direito Privado. Agravo de Instrumento $\quad n$. 2067731-23.2016.8.26.0000. Disponível em: https://esaj.tjsp.jus.br/cposg/search.do?conversationId=\&paginaConsulta=1\&localPesquisa.cd Local=$1 \&$ cbPesquisa $=$ NUMPROC $\&$ tipoNuProcesso $=$ UNIFICADO\&numeroDigitoAnoUnificado $=2$ 067731-23.2016\& foroNumeroUnificado $=0000 \&$ dePesquisaNuUnificado $=2067731-$ 23.2016.8.26.0000\&dePesquisa=\&uuidCaptcha=. Acesso em: 01 mar. 2020. 
Tribunal de Justiça de São Paulo, 13ª Câmara de Direito Privado. Agravo de Instrumento $\quad n$. 2237187-68.2016.8.26.0000. Disponível em: https://esaj.tjsp.jus.br/cposg/search.do?conversationId=\&paginaConsulta=1\&localPesquisa.cd Local=$1 \&$ cbPesquisa $=$ NUMPROC $\&$ tipoNuProcesso $=$ UNIFICADO\&numeroDigitoAnoUnificado $=2$ 237187-68.2016\&foroNumeroUnificado $=0000 \&$ dePesquisaNuUnificado $=2237187$ 68.2016.8.26.0000\&dePesquisa=\&uuidCaptcha=. Acesso em: 01 mar. 2020.

Tribunal de Justiça de São Paulo, 13 ${ }^{\mathrm{a}}$ Câmara de Direito Privado. Agravo de Instrumento $\quad n$. 2022856-60.2019.8.26.0000. Disponível em: https://esaj.tjsp.jus.br/cposg/search.do?conversationId=\&paginaConsulta=1\&localPesquisa.cd Local=-

$1 \&$ cbPesquisa=NUMPROC \& tipoNuProcesso=UNIFICADO\&numeroDigitoAnoUnificado $=2$ 022856-60.2019\&foroNumeroUnificado $=0000 \&$ dePesquisaNuUnificado $=2022856-$ 60.2019.8.26.0000\&dePesquisa=\&uuidCaptcha=. Acesso em: 01 mar. 2020.

Tribunal de Justiça de São Paulo, 13ª Câmara de Direito Privado. Agravo de Instrumento $\quad n$. 2144884-30.2019.8.26.0000. Disponível em: https://esaj.tjsp.jus.br/cposg/search.do?conversationId=\&paginaConsulta=1\&localPesquisa.cd Local=$1 \&$ cbPesquisa=NUMPROC \& tipoNuProcesso $=$ UNIFICADO \&numeroDigitoAnoUnificado $=2$ $144884-30.2019 \&$ foroNumeroUnificado $=0000 \&$ dePesquisaNuUnificado $=2144884-$ 30.2019.8.26.0000\&dePesquisa=\&uuidCaptcha=. Acesso em: 01 mar. 2020.

- Tribunal de Justiça de São Paulo, 13a Câmara de Direito Público. Agravo de Instrumento $\quad \mathrm{n}$. 2236999-12.2015.8.26.0000. Disponível em: https://esaj.tjsp.jus.br/cposg/search.do?conversationId=\&paginaConsulta=1\&localPesquisa.cd Local=-

$1 \&$ cbPesquisa $=$ NUMPROC $\&$ tipoNuProcesso $=$ UNIFICADO\&numeroDigitoAnoUnificado $=2$ 236999-12.2015\&foroNumeroUnificado $=0000 \&$ dePesquisaNuUnificado=2236999-

12.2015.8.26.0000\&dePesquisa=\&uuidCaptcha=. Acesso em: 01 mar. 2020.

Tribunal de Justiça de São Paulo, $13^{a}$ Câmera de Direito Público. Agravo de Instrumento n. 2207277-30.2015.8.26.0000. Disponível em: https://esaj.tjsp.jus.br/cposg/search.do?conversationId=\&paginaConsulta=1\&localPesquisa.cd Local=-

$1 \&$ cbPesquisa $=$ NUMPROC $\&$ tipoNuProcesso $=$ UNIFICADO\&numeroDigitoAnoUnificado $=2$ 207277-30.2015\&foroNumeroUnificado $=0000 \&$ dePesquisaNuUnificado $=2207277$ -

30.2015.8.26.0000\&dePesquisa=\&uuidCaptcha=. Acesso em: 01 mar. 2020.

Tribunal de Justiça de São Paulo, 19a Câmara de Direito Privado. Agravo de Instrumento n. 2207204-24.2016.8.26.0000. Disponível em: https://esaj.tjsp.jus.br/cposg/show.do?processo.codigo=RI003MPJQ0000\&conversationId=\& paginaConsulta $=1 \&$ localPesquisa.cdLocal $=-$

$1 \&$ cbPesquisa $=$ NUMPROC $\&$ tipoNuProcesso $=$ UNIFICADO\&numeroDigitoAnoUnificado $=1$ 030040-38.2016\&foroNumeroUnificado $=0114 \&$ dePesquisaNuUnificado $=1030040$

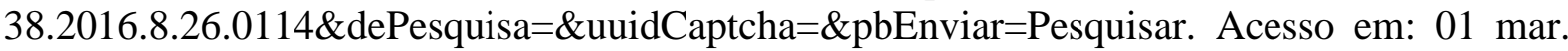
2020. 
Tribunal de Justiça de São Paulo, 19a Câmara de Direito Privado. Agravo de Instrumento $\quad \mathrm{n}$. 2257385-29.2016.8.26.0000. Disponível em: https://esaj.tjsp.jus.br/cposg/show.do?processo.codigo=RI003R9OR0000\&conversationId=\& paginaConsulta $=1 \&$ localPesquisa.cdLocal $=-$

$1 \&$ cbPesquisa $=$ NUMPROC $\&$ tipoNuProcesso $=$ UNIFICADO \&numeroDigitoAnoUnificado $=1$ 030040-38.2016\&foroNumeroUnificado $=0114 \&$ dePesquisaNuUnificado $=1030040-$

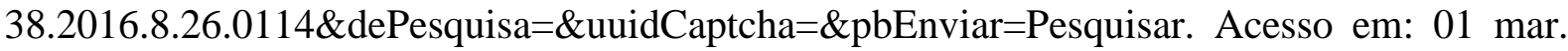
2020.

\section{$\begin{array}{lllll}\text { Instrumento } & \mathrm{n} . & 2008424-07.2017 .8 .26 .0000 . & \text { Disponível } & \text { em: }\end{array}$ https://esaj.tjsp.jus.br/cposg/search.do?conversationId=\&paginaConsulta=1\&localPesquisa.cd Local=- \\ $1 \&$ cbPesquisa=NUMPROC\&tipoNuProcesso=UNIFICADO\&numeroDigitoAnoUnificado $=2$ 008424-07.2017\&foroNumeroUnificado $=0000 \&$ dePesquisaNuUnificado $=2008424-$ 07.2017.8.26.0000\&dePesquisa=\&uuidCaptcha=. Acesso em: 01 mar. 2020.}

Tribunal de Justiça de São Paulo. Interdito Proibitório $n^{o} 1007144$ https://esaj.tjsp.jus.br/cpopg/show.do?processo.codigo=360006TWB0000\&processo.foro $=11$ 4\&processo.numero $=1007144-$

98.2016.8.26.0114\&uuidCaptcha=sajcaptcha_56f5806d19c34dc4a6ad1a16e5e0b74c. Acesso em: 01 mar. 2020.

Disponível

Tribunal de Justiça de São Paulo. Interdito Proibitório no ${ }^{o}$ 1027168-84.2015.8.26.0114. https://esaj.tjsp.jus.br/cpopg/show.do?processo.codigo=360005V700000\&processo.foro $=114$ \&processo.numero $=1027168$ -

84.2015.8.26.0114\&uuidCaptcha=sajcaptcha_56f5806d19c34dc4a6ad1a16e5e0b74c. Acesso em: 01 mar. 2020.

Disponível

Tribunal de Justiça de São Paulo. Interdito Proibitório no ${ }^{\circ} 1027512-65.2015 .8 .26 .0114$. https://esaj.tjsp.jus.br/cpopg/show.do?processo.codigo=360005VOP0000\&processo.foro $=114$ \&processo.numero=1027512-

65.2015.8.26.0114\&uuidCaptcha=sajcaptcha_56f5806d19c34dc4a6ad1a16e5e0b74c. Acesso em: 01 mar. 2020.

Tribunal de Justiça de São Paulo. $13^{\text {a }}$ Câmara de Direito Privado. Reclamação $n$. 2269185-83.2018.8.26.0000. Disponível

em: https://esaj.tjsp.jus.br/cposg/search.do?conversationId=\&paginaConsulta=1\&localPesquisa.cd Local=-

$1 \&$ cbPesquisa $=$ NUMPROC $\&$ tipoNuProcesso $=$ UNIFICADO\&numeroDigitoAnoUnificado $=2$ 269185-83.2018\&foroNumeroUnificado $=0000 \&$ dePesquisaNuUnificado $=2269185$ -

83.2018.8.26.0000\&dePesquisa=\&uuidCaptcha=. Acesso em: 01 mar. 2020

. Tribunal de Justiça de São Paulo. Reintegração de Posse $n^{o}$ 102204078.2018.8.26.0114. Disponível em: https://esaj.tjsp.jus.br/cpopg/show.do?processo.codigo $=36000 \mathrm{E} 7440000 \&$ processo.foro $=114$ 
\&processo.numero $=1022040-$

78.2018.8.26.0114\&uuidCaptcha=sajcaptcha_89667e58edfd4152a6664a7f7f384ddf. Acesso em: 01 mar. 2020.

- Tribunal de Justiça de São Paulo. Reintegração de Posse n. 103004038.2016.8.26.0114. Disponível em: https://esaj.tjsp.jus.br/cpopg/show.do?processo.codigo=360007W510000\&processo.foro=84 \&processo.numero $=1030040$ -

38.2016.8.26.0114\&uuidCaptcha=sajcaptcha_89667e58edfd4152a6664a7f7f384ddf. Acesso em: 01 mar. 2020.

. Tribunal de Justiça de São Paulo. Reintegração de Posse n. 100268427.2017.8.26.0084. Disponível em: https://esaj.tjsp.jus.br/cpopg/show.do?processo.codigo=2C0001E5D0000\&processo.foro=84 \&processo.numero=1002684-

27.2017.8.26.0084\&uuidCaptcha=sajcaptcha_89667e58edfd4152a6664a7f7f384ddf. Acesso em: 01 mar. 2020.

66 Tribunal de Justiça de São Paulo. Reintegração de Posse n. 000017866.2015.8.26.0084. Disponível em: https://esaj.tjsp.jus.br/cpopg/show.do?processo.foro=84\&processo.codigo=2C0000LGW0000 \&uuidCaptcha=sajcaptcha_bd102d640f4a44eb91e950f22586de63. Acesso em: 01 mar. 2020.

Tribunal de Justiça de São Paulo, 19a Câmara de Direito Privado. Mandado de

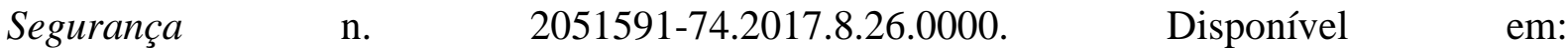
https://esaj.tjsp.jus.br/cposg/show.do?processo.codigo=RI003WQU80000\&conversationId=\& paginaConsulta $=1 \&$ localPesquisa.cdLocal $=-$

$1 \&$ cbPesquisa=NUMPROC\&tipoNuProcesso=UNIFICADO\&numeroDigitoAnoUnificado $=1$ 030040-38.2016\&foroNumeroUnificado $=0114 \&$ dePesquisaNuUnificado $=1030040-$

38.2016.8.26.0114\&dePesquisa $=\&$ uuidCaptcha $=\&$ pbEnviar=Pesquisar. Acesso em: 01 mar. 2020.

\section{BIBLIOGRAFIA}

BONILHA, Giovana Milano. Crônicas de despejos anunciados: análise das decisões em conflitos fundiários urbanos. Rev. Direito Práxis, Rio de Janeiro, Vol. 9, N. 3, p. 1249-1283, 2018. DOI: 10.1590/2179-8966/2017/29547. Disponível em: https://www.epublicacoes.uerj.br/index.php/revistaceaju/article/view/29547/21562. Acesso em: 08 jun. 2020.

BARACHO, Hertha Urquiza; BRISOLA; Anna Karla da Silva Brisola; Junior José da Silva Alves. A responsabilidade social empresarial como mecanismo à proteção integral de crianças e adolescentes. Rev. Juris Poiesis, Rio de Janeiro, Vol. 22, N. 29, p. 104-117, 2019. Disponível em: $\quad$ http://periodicos.estacio.br/index.php/jurispoiesis/article/viewFile/6638/47965678. Acesso: 08 jun. 2020.

FUNDO DAS NAÇÕES UNIDAS PARA A INFÂNCIA. Pobreza na Infância $e$ na Adolescência. Portal Eletrônico do Fundo das Nações Unidas para Infância (versão online) Brasil, ago. 2018.2 Disponível em: 
https://www.unicef.org/brazil/media/156/file/Pobreza_na_Infancia_e_na_Adolescencia.pdf. Acesso em: 08 jun. 2020.

LINS, REGINA DULCE; ROLNIK, RAQUEL (org.). Observatório de Remoções 2017-2018: relatório bianual. (Versão online). São Paulo: FAU USP, 2018. Disponível em http://www.labcidade.fau.usp.br/observatorio-de-remocoes-apresenta-o-relatorio-2017-2018/. Acesso em: 08 jun. 2020.

MARICATO, Ermínia. O impasse da política urbana no Brasil. São Paulo: Editora Vozes, 2010. 214 p.

MIAGUSKO, Edson. Movimentos de moradia e sem teto em São Paulo: experiências no contexto do desmanche. São Paulo: Alameda, 2012. 343 p. ISBN 978-8579390845.

MINISTÉRIO PUBLICO DO ESTADO DE SÃO PAULO. Atuação do Ministério Público em Conflitos Possessórios Coletivos. Cartilha (versão online), out. 2017, p. 24. Disponível em: http://www.mpsp.mp.br/portal/page/portal/Cartilhas/atuacao-MP-conflitos-possessorioscoletivos.pdf. Acesso em: 08 jun. 2020.

MINISTÉRIO PUBLICO DO ESTADO DO PARANÁ. Diretrizes para a Polícia Destinada ao Atendimento de Crianças e Adolescentes. (versão online no portal eletrônico do Ministério Público do Estado do Paraná), Brasil, jan. 2014. Disponível em: http://www.crianca.mppr.mp.br/pagina-1590.html. Acesso em: 08 jun. 2020.

ORGANIZAÇÃO DAS NAÇÕES UNIDAS. Comitê dos Direitos Econômicos, Sociais e Culturais. Comentário Geral n. 4: O Direito à Moradia Adequada (artigo 11.1 do Pacto), 13 dez. 1991, E/1992/23. Disponível em: https://www.refworld.org/docid/47a7079a1.html. Acesso em: 08 jun. 2020.

Comitê dos Direitos Econômicos, Sociais e Culturais. Comentário Geral n. 7: $O$ Direito à Moradia Adequada (artigo 11.1 do Pacto): remoções forçadas, 20 mai. 1997, E/1998/22. Disponível em: http://www.refworld.org/docid/47a70799d.html. Acesso em: 08 jun. 2020.

Como atuar em projetos que envolvem despejos e remoções? Portal eletrônico da relatoria especial para moradia adequada (versão online), Brasil, ago. 2010. Disponível em: https://apublica.org/wp-content/uploads/2012/04/GUIA_REMOCOES_portugues_20119.pdf. Acesso: 08 jun. 2020.

ROLNIK, Raquel. Guerra dos Lugares: A colonização da terra e da moradia na era das finanças. São Paulo: Boitempo, 2015. 424 p.

TRINDADE, Thiago Aparecido. Protesto e Democracia: Ocupações Urbanas e Luta pelo Direito à Cidade. Edição. Jundiaí: Paco Editorial, 2017. 300 p.

Data de Submissão: 21/06/2020

Data de Aceite: 18/09/2020 